\title{
DGGE-based detection method for Quahog Parasite Unknown (QPX)
}

\author{
R. J. Gast ${ }^{1, *}$, E. Cushman ${ }^{2}$, D. M. Moran ${ }^{1}$, K. R. Uhlinger ${ }^{3}$, D. Leavitt ${ }^{4}$, \\ R. Smolowitz ${ }^{3}$ \\ ${ }^{1}$ MS \#32, Biology Department, Woods Hole Oceanographic Institution, Woods Hole, Massachusetts 02543, USA \\ ${ }^{2}$ Biology Department, Palm Beach Atlantic University, West Palm Beach, Florida 33409, USA \\ ${ }^{3}$ Laboratory for Aquatic Animal Medicine and Pathology, Marine Biological Laboratory, Woods Hole, \\ Massachusetts 02543, USA \\ ${ }^{4}$ Center for Economic and Environmental Development, Roger Williams University, Bristol, Rhode Island 02809, USA
}

\begin{abstract}
Quahog Parasite Unknown (QPX) is a significant cause of hard clam Mercenaria mercenaria mortality along the northeast coast of the United States. It infects both wild and cultured clams, often annually in plots that are heavily farmed. Subclinically infected clams can be identified by histological examination of the mantle tissue, but there is currently no method available to monitor the presence of QPX in the environment. Here, we report on a polymerase chain reaction (PCR)based method that will facilitate the detection of QPX in natural samples and seed clams. With our method, between 10 and 100 QPX cells can be detected in $1 \mathrm{l}$ of water, $1 \mathrm{~g}$ of sediment and $100 \mathrm{mg}$ of clam tissue. Denaturing gradient gel electrophoresis (DGGE) is used to establish whether the PCR products are the same as those in the control QPX culture. We used the method to screen 100 seed clams of $15 \mathrm{~mm}$, and found that 10 to $12 \%$ of the clams were positive for the presence of the QPX organism. This method represents a reliable and sensitive procedure for screening both environmental samples and potentially contaminated small clams.
\end{abstract}

KEY WORDS: Quahog Parasite Unknown · Detection limit · Seed clams $\cdot$ SSU rDNA

\section{INTRODUCTION}

Quahog Parasite Unknown (QPX) was identified in 1995 in both Provincetown and Duxbury, Massachusetts, USA, as the cause of significant morbidity and mortality (up to $90 \%$ ) of cultured hard clams Mercenaria mercenaria (Smolowitz et al. 1998). The disease was first noted in Canadian clams in the early 1960s (Drinnan \& Henderson 1963), and was labeled QPX (Quahaug Parasite X) by Whyte et al. (1994) after causing significant mortality of hatchery clams at Prince Edward Island, Canada, in 1989. Currently, the parasite and accompanying hard clam mortality can be detected in cultured and wild clams in bays and estuaries from Canada to Virginia. Farmed clams are an outgrowth of the profitable wild fishery, and quahogs of these 2 industries often coexist in the same bodies of water. In 1995, hard clam aquaculture was worth $\$ 25.3$ million in the northeast of North America, with Massachusetts contributing approximately $1 / 5$ of the total landed value (Spatz et al. 1996). The bulk of quahog farming in Massachusetts takes place on the flats of Cape Cod and significantly contributes to the local economy, as well as to the traditional maritime activities of the region. QPX has been, and continues to be, a significant threat to this important industry.

The QPX organism has been isolated and is currently in culture (Kleinschuster et al. 1998). Work with cultured QPX demonstrated that it grew best at $24^{\circ} \mathrm{C}$, a pH of 8 and a salinity of 34 (Brothers et al. 2000). Additionally, it has been shown that QPX is a directly infective organism (Smolowitz et al. 2001). Although the disease has been found in wild clams, it is most often seen in heavy sets of farmed animals, as would be expected for a directly infective organism. Clam mortality in infected plots can reach $80 \%$ or more, and appears to be most 
severe in the spring and fall. Mortality occurs primarily in clams of submarket size (1" valve width or $2.5 \mathrm{~cm})$, but small seed clams ( 1 to $20 \mathrm{~mm}$ ) originating directly from hatcheries and nurseries do not appear to be infected by the organism (Ford et al. 1997).

Using small-subunit ribosomal RNA gene sequences (SSU rRNA), QPX has been taxonomically placed into the protistan order Labyrinthulida, family Thraustochytriidae (Maas et al. 1999). A diverse collection of labyrinthulid organisms is commonly found in the marine environment and is also commonly found within the mantle fluid of bivalves. To date, SSU rRNA sequences from QPX-infected clams collected from Canada, Massachusetts, New Jersey and Virginia have indicated that QPX isolates are closely related (Stokes et al. 2002), suggesting that a single species may be the causative agent of the disease.

QPX is a significant cause of bivalve mortality over a wide range of habitats, and can seriously affect fisheries in those areas. The distribution of the organism in the environment or in reservoirs outside of infected clams is currently unknown, but has significance with regard to management of contaminated plots and regions. There is also the potential that QPX may be imported into an area along with adult hard clams or seed that are relayed in shellfish aquaculture or restoration projects. Since relaying clams along the east coast was a common practice for several years, spread of the directly infective disease between sites may have occurred (R. E. Drinnan pers. comm.).

Identification of the QPX organism and/or its reservoir in the environment is an important component to advancing our understanding of its distribution, transfer between clams and/or other alternate hosts, mechanisms behind the severity of development of the disease within a population, and its possible long-term effects on commercially exploited hard clam populations. Therefore, we set out to develop sensitive and specific techniques, building upon polymerase chain reaction (PCR) primers currently available for the QPX organism, to survey for the parasite in the field. We developed a nested PCR protocol that generates a product for analysis by denaturing gradient gel electrophoresis (DGGE) to detect the QPX organism, and used this method to examine seed clams for the presence of QPX.

\section{MATERIALS AND METHODS}

Detection limit. QPX cell cultures obtained from Dr. Smolowitz were pelleted at maximum speed in a Model CL International Clinical Centrifuge for $15 \mathrm{~min}$ at room temperature, then washed 2 times with sterile seawater. This approach disrupted the mucous formed by the culture as well as many of the sporangia, enabling accurate counts of cells and spores using a Palmer Maloney slide. Dilutions of the washed culture in $0.2 \mu \mathrm{m}$ filtered, sterile seawater were made from 10000 cells down to 0 cells. These dilutions were collected separately on $25 \mathrm{~mm}, 0.8 \mu \mathrm{m}$ pore size polycarbonate filters (Millipore) and frozen at $-20^{\circ} \mathrm{C}$ until combined with samples of seawater $(200 \mathrm{ml})$, sediment $(1 \mathrm{~g})$ and clam tissue $(100 \mathrm{mg})$.

Water and sediment samples were obtained from Eel Pond in Woods Hole, MA, USA, an area not reported to have QPX infections. Water was collected in sterile polycarbonate bottles, then $200 \mathrm{ml}$ aliquots were filtered onto separate $47 \mathrm{~mm}, 0.8 \mu \mathrm{m}$ polycarbonate filters. One water filter was placed into each of the tubes in a set of QPX dilution series filters. Marine sediment was collected using sterile, $50 \mathrm{ml}$ conical tubes as corers. In the laboratory, $1 \mathrm{~g}$ subsamples were established and added directly to each tube in a set of the QPX dilution series filters. A littleneck clam was purchased from a grocery store, and the outside surfaces were scrubbed with water followed by ethanol. The clam was opened, and the mantle and siphon tissue removed and rinsed in sterile, distilled water. Clam tissue was cut into $100 \mathrm{mg}$ pieces using a new razor blade and macerated in $1.5 \mathrm{ml}$ microcentrifuge tubes with $600 \mu \mathrm{l}$ lysis buffer using sterile pestles and a small number of zircon beads (Gast et al. 2004). A QPX dilution series filter was then added to each tube, and the extraction process continued. Water and clam samples were processed for the extraction of nucleic acids using the hot detergent method (Gast et al. 2004). Nucleic acids were extracted from sediment samples using the MoBio UltraClean Soil DNA Kit within $12 \mathrm{~h}$ of sediment collection and without freezing the sample. We have found that freezing sediment samples can reduce the efficiency of DNA extraction.

A positive control for the QPX organism was generated from $1 \mathrm{ml}$ of the washed QPX culture. The cells were pelleted at maximum speed in a microcentrifuge for $10 \mathrm{~min}$, then nucleic acids were extracted following the hot detergent protocol for water samples (Gast et al. 2004). One microliter of the extract was used in amplifications to establish the correct size for the QPX culture DGGE product on agarose gels and to generate a positive marker for the QPX organism on denaturing gradient gels.

Seed clams. One-hundred $15 \mathrm{~mm}$ seed clams (size from the hinge to the front edge of the shell) were obtained from 2 different suppliers (50 each; Groups A and B). Shells were rinsed with ethanol prior to opening, and the mantle and siphon were removed and placed in sterile, $1.5 \mathrm{ml}$ centrifuge tubes. Samples were stored frozen at $-20^{\circ} \mathrm{C}$ until extraction. Extraction followed the hot detergent protocol for spiked clam tissue described above. 
Primers and nested PCR amplification. The nested amplification detection procedure has 3 stages, but all PCR reactions were set up the same. Each reaction volume was $50 \mu \mathrm{l}$, with $1 \mu \mathrm{l}$ of template DNA, $100 \mathrm{ng}$ of each primer, $0.2 \mathrm{mM}$ of each nucleotide and $2.5 \mathrm{mM}$ of $\mathrm{MgCl}_{2}$. In the first step, the thraustochytrid primers FA2 and RA3 (Mo et al. 2002) were used, with 20 cycles of $30 \mathrm{~s}$ at $95^{\circ} \mathrm{C}, 30 \mathrm{~s}$ at $63^{\circ} \mathrm{C}$ and $1 \mathrm{~min}$ at $72^{\circ} \mathrm{C}$. At the end of the 25 cycles, a 3 min hold at $72^{\circ} \mathrm{C}$ was used to fully extend all products. The first reaction was diluted $1: 10$, and $1 \mu \mathrm{l}$ was re-amplified with the parasitespecific primers QPXF and QPXR2 (Stokes et al. 2002), using 25 of the same PCR cycles. The annealing temperature of $63^{\circ} \mathrm{C}$ was determined to be optimal for both FA2/RA3 and QPXF/QPXR2 primer sets at the stated $\mathrm{Mg}^{+2}$ concentration using the gradient function of an Eppendorf Mastercycler. The final round of nested amplification used $1 \mu \mathrm{l}$ of the second PCR reaction with 960GC (Gast et al. 2004) and QPXR2 as the primers, with a touchdown amplification strategy (Gast et al. 2004). The initial annealing temperature was $65^{\circ} \mathrm{C}$ for 2 cycles $\left(45 \mathrm{~s}\right.$ at $95^{\circ} \mathrm{C}, 45 \mathrm{~s}$ at $65^{\circ} \mathrm{C}, 45 \mathrm{~s}$ at $72^{\circ} \mathrm{C}$ ), followed by a decrease in annealing temperature of $2^{\circ}$ every 2 cycles down to $55^{\circ} \mathrm{C}$. Forty cycles were then carried out at the $55^{\circ} \mathrm{C}$ annealing temperature $\left(45 \mathrm{~s}\right.$ at $95^{\circ} \mathrm{C}, 45 \mathrm{~s}$ at $55^{\circ} \mathrm{C}, 45 \mathrm{~s}$ at $\left.72^{\circ} \mathrm{C}\right)$. Products from the DGGE amplification were detected on $1 \%$ agarose gels stained with ethidium bromide prior to analysis on denaturing gels.

DGGE method. The 960GC/QPXR2 products were precipitated overnight at $-20^{\circ} \mathrm{C}$ with $0.3 \mathrm{M}$ sodium acetate and $0.6 \mathrm{vol}$ of isopropanol. Products were pelleted by microcentrifugation at maximum speed in a microcentifuge for $10 \mathrm{~min}$. The pellets were allowed to air dry and then resuspended in $5 \mu \mathrm{l}$ of sterile, distilled water and $5 \mu \mathrm{l}$ of DGGE loading dye $(40 \%$ Ficoll 400 , $10 \mathrm{mM}$ Tris $\mathrm{pH} 7.8,1 \mathrm{mM}$ EDTA, $0.1 \%$ bromphenolblue). A volume of 3 to $5 \mu \mathrm{l}$ was loaded per lane on the gel. DGGE gels were run with a denaturing gradient of 45 to $75 \%$ urea at $60^{\circ} \mathrm{C}$ at $95 \mathrm{~V}$ overnight (16 h) using the CBS Scientific Model DGGE-2000 gel apparatus. This gradient was determined to provide optimal separation for the 960GC/QPXR2 product based upon perpendicular gel analysis. Bands were visualized by staining the gel in $1 \times$ TAE ( $40 \mathrm{mM}$ Tris base, $20 \mathrm{mM}$ sodium acetate, $1 \mathrm{mM}$ EDTA, adjusted $\mathrm{pH}$ to 7.4 with acetic acid) with ethidium bromide for $10 \mathrm{~min}$, followed by 20 min destaining in distilled water. Digital images were obtained using the ChemiImager System (Alpha Innotech Corporation).

Sequencing of DGGE bands. Bands were recovered from the DGGE gel by touching the band with a sterile, aerosol-resistant pipette tip, and then pipetting up and down several times in $5 \mu \mathrm{l}$ of sterile, distilled water. Two microliters were reamplified using 960fb (non-GC clamped primer) and QPXR2. These products were precipitated with isopropanol as described above to remove excess primers, then resuspended in $10 \mu \mathrm{l}$ of sterile Milli-Q water. Five microliters of product were sequenced directly using ABI Prism Big Dye Terminator Cycle Sequencing Ready Reaction Mix and the 960fb or QPXR2 primers. Sequencing reactions were run on an ABI 377 (PE Applied Biosystems) and analyzed using Sequencher 4.2.2 (Gene Codes Corporation).

\section{RESULTS}

\section{Detection limit}

The nested amplification procedure is itself a very sensitive detection method for QPX. The results for the determination of the limit of detection of QPX cells in a background of environmental DNA are shown in Fig. 1. The spiked water samples in Fig. 1A show the QPX band appearing in all samples down to 10 cells $200 \mathrm{ml}^{-1}$

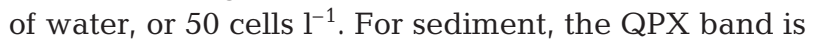
present in the samples from 10000 down to 10 cells g $^{-1}$ of sediment (Fig. 1B, C). Fig. 1D shows similar results for the QPX-spiked clam tissues, where the QPX band is again recoverable down to 10 cells $100 \mathrm{mg}^{-1}$ of tissue. Larger bands were sometimes present in the lanes for all 3 sample types. The ones present in the lanes with QPX products were usually dimers or trimers of the QPX fragment (crosses in Fig. 1A), but the bands in Lanes 1 and 2 of the spiked sediment gel (asterisks in Fig. 1B) were actually products from another template (see DGGE analysis). We found that their presence could be reduced or eliminated from the spiked samples by performing 20 cycles instead of 25 in the FA2/RA3 amplification (Fig. 1C), and this is the amplification strategy that we currently use.

\section{DGGE analysis}

Confirmation that the predicted QPX PCR bands observed in the spiked environmental samples correspond to the QPX parasite was accomplished by DGGE of the samples. Bands that migrate to the same position in the DGGE gel are usually the same sequence, while bands at other positions have different sequences. DGGE banding patterns obtained for the spiked sediment and water samples are shown in Fig. 2. The spiked samples with QPX-sized amplification products all have bands that match those obtained from the QPX culture (Lanes 1 to 4 and 9 to 12; Fig. 2). The QPX culture lanes show a prominent band along with several less intense bands. This could be due to an 

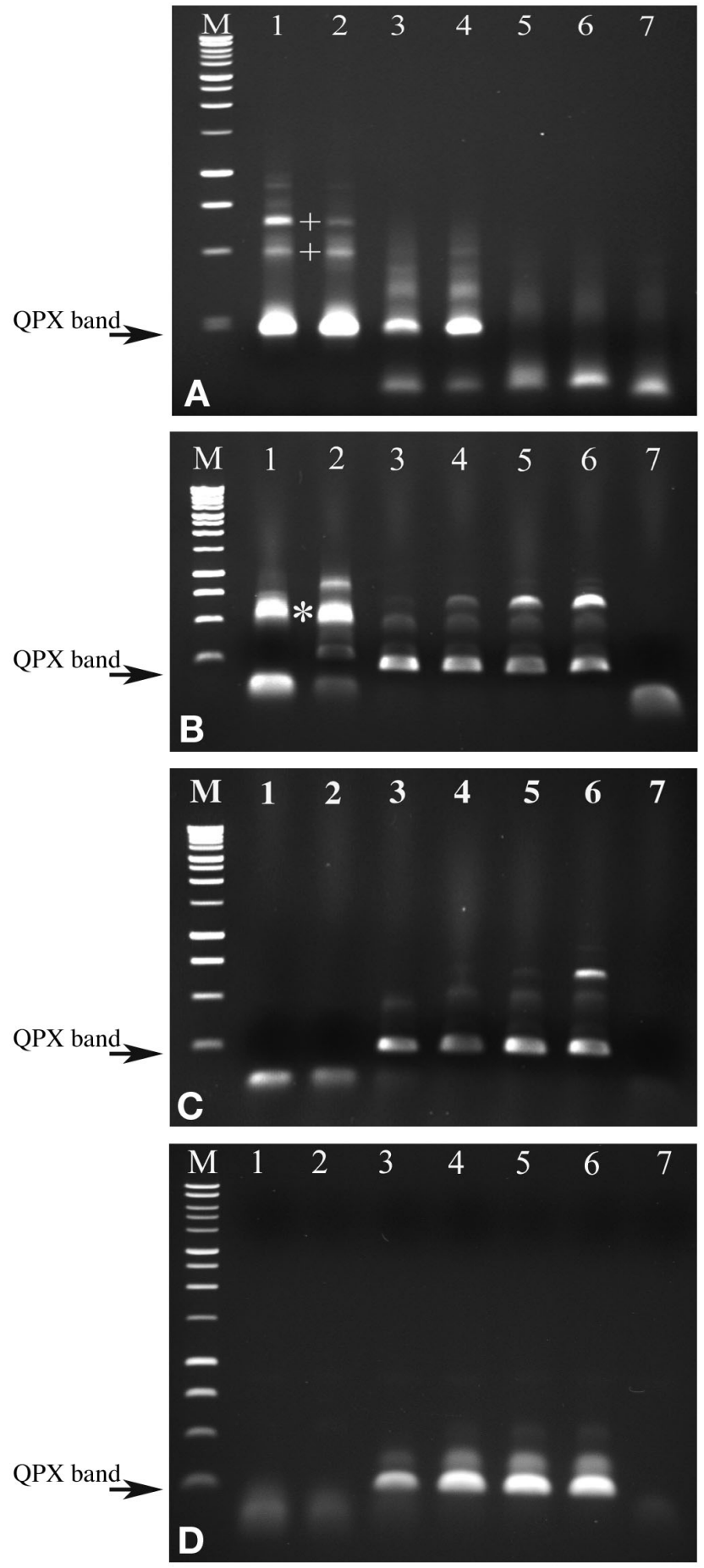

amplification artifact, the presence of multiple copies of slightly different ribosomal genes in the same cell, or the fact that the QPX culture is not clonal and might represent a mixture of very similar strains. The 2 reactions that showed larger products in the spiked sediment dilution series (Lanes 1 \& 2; Fig. 1B) revealed unique bands on the DGGE gel (data not shown), but no QPX bands.
Fig. 1. Ethidium bromide-stained $1 \%$ agarose gel showing the 960GC/QPXR2 polymerase chain reaction (PCR) products for QPX (Quahog Parasite Unknown) dilution series. (A) Seawater: Lane M, $1 \mathrm{~kb}$ ladder (Promega); Lane 1, 10000 QPX cells $200 \mathrm{ml}^{-1}$; Lane 2, 1000 QPX cells $200 \mathrm{ml}^{-1}$; Lane 3, 100 QPX cells $200 \mathrm{ml}^{-1}$; Lane 4, 10 QPX cells $200 \mathrm{ml}^{-1}$; Lane 5, $1 \mathrm{QPX}$ cell $200 \mathrm{ml}^{-1}$; Lane 6, 0 QPX cells $200 \mathrm{ml}^{-1}$; Lane 7, no template control for PCR contamination (+: dimer and trimer of QPX product). (B) Sediment and (C) sediment amplified with 20 cycles of FA2/RA3, 25 cycles of QPXF/QPXR2, followed by denaturing gradient gel electrophoresis (DGGE) touchdown cycles: Lane M, $1 \mathrm{~kb}$ ladder (Promega); Lane 1, 0 QPX cells $\mathrm{g}^{-1}$; Lane 2, 1 QPX cell g ${ }^{-1}$; Lane 3, 10 QPX cells $\mathrm{g}^{-1}$; Lane 4, 100 QPX cells $\mathrm{g}^{-1}$; Lane 5, 1000 QPX cells $\mathrm{g}^{-1}$; Lane 6, 10000 QPX cells g ${ }^{-1}$; Lane 7, no template control for PCR contamination (asterisk: platyhelminth band). (D) Clam tissue: Lane M, 1 kb ladder (Promega); Lane 1, 0 QPX cells $100 \mathrm{mg}^{-1}$; Lane 2, 1 QPX cell $100 \mathrm{mg}^{-1}$; Lane 3, 10 QPX cells $100 \mathrm{mg}^{-1}$; Lane 4, 100 QPX cells $100 \mathrm{mg}^{-1}$; Lane 5, 1000 QPX cells $100 \mathrm{mg}^{-1}$; Lane 6, 10000 QPX cells $100 \mathrm{mg}^{-1}$; Lane 7, no template control for PCR contamination

DGGE is able to separate fragments with a single base difference, so the multiple bands at different positions in the spiked samples may represent variability within the culture, the ribosomal repeat unit, or PCR errors that accumulate during the multiple rounds of amplification. When multiple sequences that are very similar are the target for amplification, they can form heteroduplexes during the repeated rounds of PCR

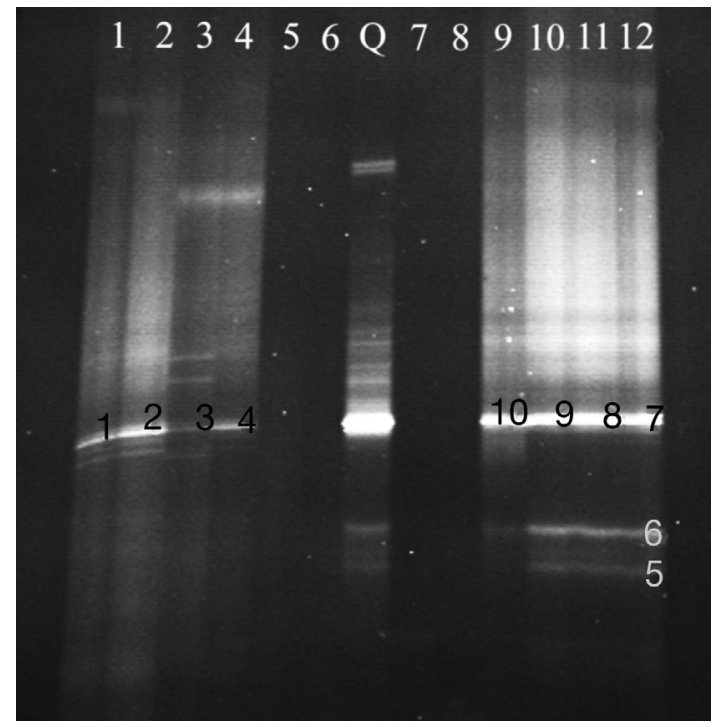

Fig. 2. DGGE of water and sediment limits of detection: Lane Q, QPX culture; Lanes 1-6, spiked seawater (200 ml). Lane 1, 10000 cells; Lane 2, 1000 cells; Lane 3, 100 cells; Lane 4, 10 cells; Lane 5,1 cell; Lane 6, 0 cells. Lanes 7-12, spiked sediment (1 g). Lane 7, 0 cells; Lane 8, 1 cell; Lane 9, 10 cells; Lane 10, 100 cells; Lane 11, 1000 cells; Lane 12, 10000 cells. Numbers indicate bands recovered from gel for reamplification and sequencing. Band reference numbers for Fig. 5 are 021605.1 to 021605.10 
(Kanagawa 2003). These heteroduplexes occur as multiple bands on DGGE gels, but show very little sequence variation. We were not able to establish whether repeat unit variation or strain variation in the culture was the source of the additional bands in the spiked reactions, and recognize the need to continue to pick and sequence bands that occur in natural samples to further examine potential strain variation.

Bands that co-migrated to the same position as the major QPX culture band were picked from the gel and sequenced, which confirmed their identity as QPX in sequence alignments (Fig. 3). Bands at other positions were also recovered, reamplified and sequenced to determine their identity. The additional bands picked in Fig. 2 (Lane 12, Bands 021605.5 and 021605.6) are QPX-like (Fig. 3) and are also present in the QPX control samples. The unique DGGE bands from the spiked sediment experiment were most prevalent in the 0 and 1 cell reactions. Their sequences returned BLAST (Altschul et al. 1997) results indicating similarity to a platyhelminth (Phonorhyncus helgolandicus). Alignment with the QPX DGGE band sequences in Fig. 3 shows a distinct insert region in these sequences (021605.12, 021605.13 and 021605.14). These bands were once observed in the spiked clam amplifications, but have been absent in subsequent nested amplifications. This suggests the potential contamination of PCR reactions with previous products or templates that

T. sp. C9G
T. pachydermum
QPX Stokes
QPX Ragan
QPX Maas
021605.1
021605.2
021605.3
021605.4
021605.5
021605.6
021605.7
021605.8
021605.9
021605.10
A3
A25
A35
A40
B18
B22
B24
B29
021605.12
021605.13
021605.14

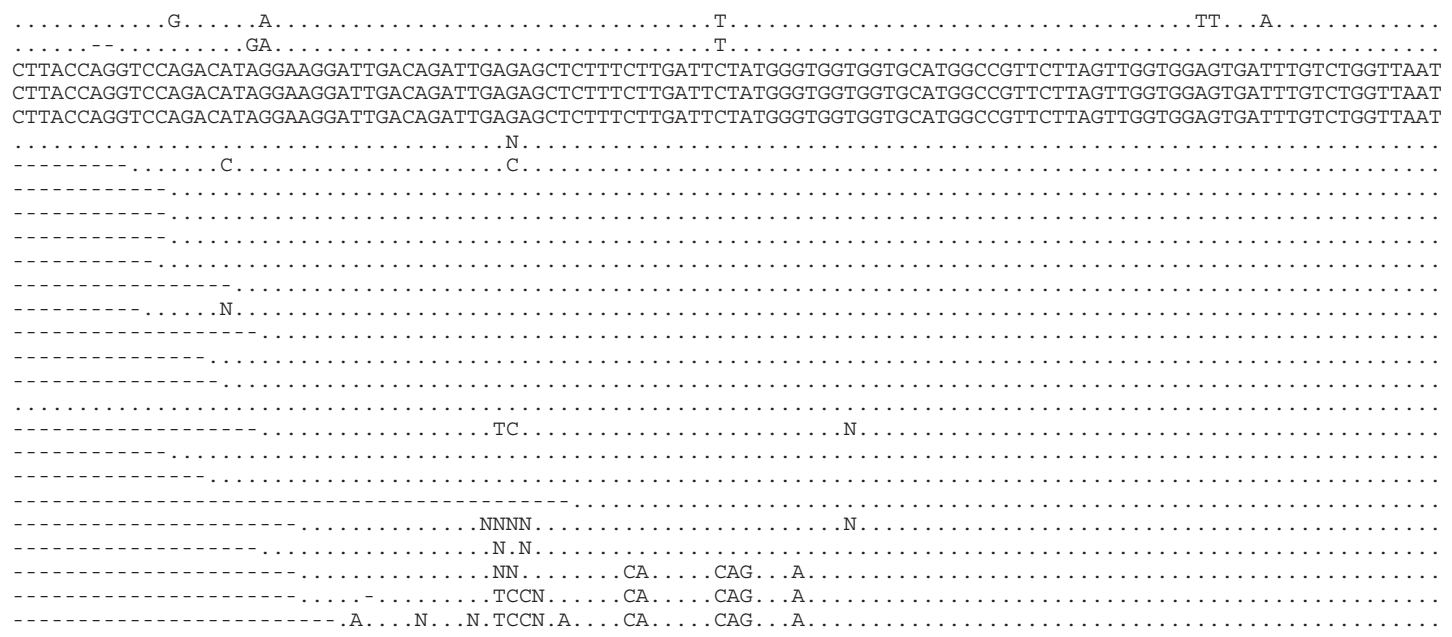

T. $\mathrm{sp} . \mathrm{C} 9 \mathrm{G}$

T. pachydermum

QPX stokes

QPX Ragan

QPX Maas

021605.1

021605.2

021605.3

021605.4

021605.5

021605.6

021605.7

021605.8

021605.9

021605.10

021605
A3
A2 5
A 35

A2 5
A3 5

A 40

B18

B2 2

B2 4

B29

021605.12

021605.13

021605.14

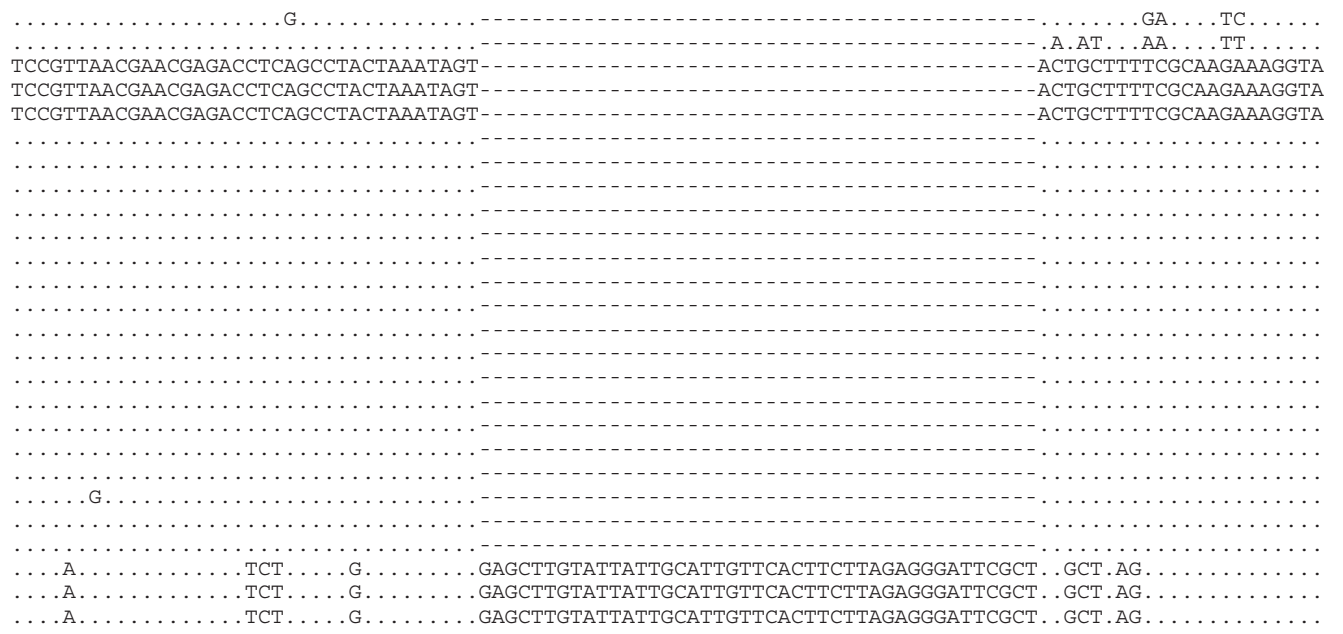

Fig. 3. Sequence alignment of DGGE products from spiked water and sediment, and environmental seed clams with a fragment of the small subunit ribosomal gene from QPX and other thraustochytrids (Positions 1164 to 1331 in the QPX sequence). Sequences 021605.12, 021605.13 and 021605.14 are DGGE band sequences for the large fragment in Lanes 1 and 2 of Fig. 1B. Thraustochytrium pachydermum (AB022113) and Thraustochytrium sp. C9G (AF474172) are thraustochytrid sequences most similar to QPX. QPX Stokes (AY052644), QPX Ragan (AF261664) and QPX Maas (AF155209) are sequences for the QPX organism from GenBank (dashes in the alignment: gaps; dots: the same base as the QPX sequence; letters: base differences) 
accumulated to a significant level through the rounds of nested PCR, although our negative controls never showed a product. We have observed this contamination to occur when doing repeated amplifications of a target sequence, despite setting up reactions in a separate laboratory where PCR products or genomic DNA are never analyzed. Aliquoting and routinely replacing reagents, and wiping down bench surfaces with diluted hydrochloric acid have significantly reduced episodes of contamination.

The specificity of amplification primers is always a question, and the amplification of platyhelminth sequences suggested less than optimal performance. The FA2/RA3 and QPXF/QPXR2 primers were designed and tested by other researchers (Mo et al. 2002, Stokes et al. 2002). We re-examined their specificity relative to sequences in current databases through BLAST (Altschul et al. 1997) searches of GenBank for short, nearly identical sequences and Check Probe at the Ribosomal Database Project (Cole et al. 2005). Our searches found no strong matches to anything other than the target for the QPX-specific primers, but the primers that were supposed to be thraustochytrid specific (FA2 and RA3) actually targeted a wide range of other organisms as well. Although FA2 and RA3 are less specific than originally thought, they are still useful for the first round of PCR, because they can increase the amount of target for the QPX primers that follow. Without this amplification step, we have noted about a 10- to 100-fold reduction in our detection limit (data available by request). The QPXF and QPXR2 primers appear to still be useful for QPX organisms. Despite the fact that BLAST matches for QPXF and QPXR2 were very specific, we do see amplification of a platyhelminth sequence when using them. Therefore, we cannot rule out the potential that other environmental sequences might cross-react with the primers, and rely on amplicon size and the DGGE method to identify QPX positives.

\section{Seed clams}

A total of 50 seed clams from Group A and 50 of the seed clams from Group B were examined using the nested PCR procedure. Six clams from the A group and 5 clams from the B group yielded final products for DGGE analysis (e.g. Lanes 5 and 7; Fig. 4). When run on DGGE gels (Fig. 5), products were present at the same position as the QPX control, as well as at several other positions in each lane. Most of the samples on the left side of the gel have been overloaded because the amount of DNA being added was not quantifiable at the time, giving the gel a messy appearance. Regardless, the presence of QPX was confirmed by the recov-

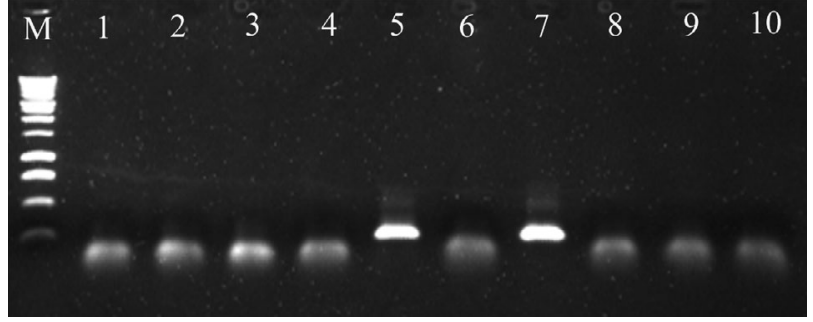

Fig. 4. Ethidium-bromide-stained 1\% agarose gel of a subset of seed clam Group A 960GC/QPXR2 amplification products: Lane M, $1 \mathrm{~kb}$ ladder (Promega); Lane 1, A42; Lane 2, A43; Lane 3, A44; Lane 4, A45; Lane 5, A46; Lane 6, A47; Lane 7, A48; Lane 8, A49; Lane 9, A50; Lane 10, no template control for PCR contamination. Lanes 5 and 7 show product of the correct size for QPX. The 'band' present in Lanes 1 to 4, 6 and 8 to 10 is unincorporated primer

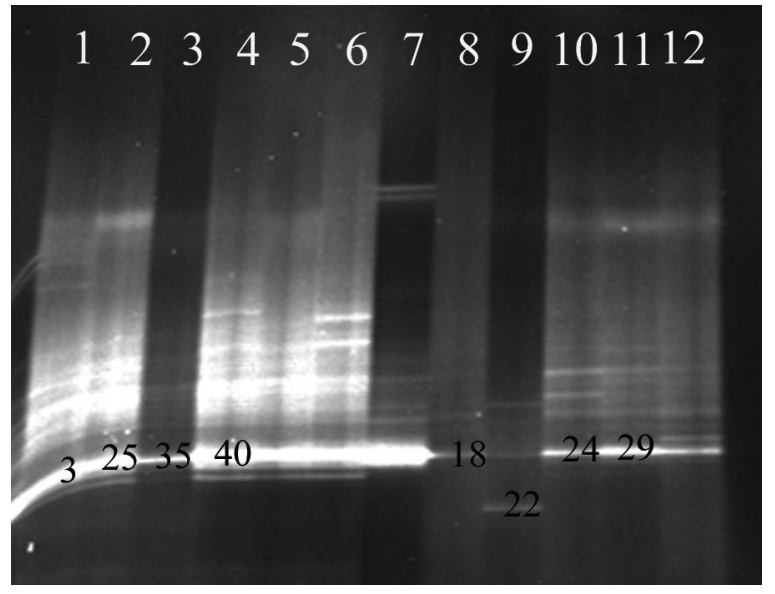

Fig. 5. DGGE analysis of 960GC/QPXR2 PCR products from seed clam Groups A and B. Lane 1, A3; Lane 2, A25; Lane 3, A35; Lane 4, A40; Lane 5, A46; Lane 6, A48; Lane 7, QPX culture; Lane 8, B18; Lane 9, B22; Lane 10, B24; Lane 11, B29; Lane 12, B30. Numbers indicate bands recovered from gel for reamplification and sequencing. Band reference numbers correspond to the sample and are A3, A25, A35, A40, B18, B22, B24 and B29

ery of bands from this gel, sequencing, alignment and comparison (Fig. 3). These results indicate QPX presence at levels of $12 \%$ (Group A) and 10\% (Group B) in the $15 \mathrm{~mm}$ seed clams.

\section{DISCUSSION}

This manuscript details the development of a sensitive and specific method for the detection of the hard clam parasite QPX. The nested PCR protocol is able to routinely detect between 10 and 50 cells $\mathrm{l}^{-1}$ water or $\mathrm{g}^{-1}$ sediment. It is currently unknown whether this 
very low level of detection is relevant for the infection of clams, but it is necessary for a survey of environmental samples. Although we do not know the actual number of QPX cells to expect in environmental samples, it seems likely that as free-living organisms they might be present at levels similar to other protists. Abundances of protists between 2 and $200 \mu \mathrm{m}$ in size

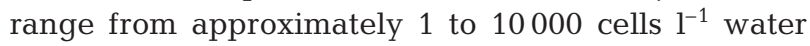
(Austin 1988). Therefore, our level of detection is appropriate for monitoring natural samples for the presence and persistence of QPX as a free-living organism.

Our method is useful because it is sensitive and can be adapted to screening a large number of samples relatively quickly (96-well format). Combined with DGGE analysis, the method becomes even more specific for the QPX organism by providing a means to compare the bands recovered from environmental samples or infected clams with those from the QPX strain(s) currently in culture. This could enable assessment of whether genetically distinct QPX isolates have been detected. To date, all known sequences for QPXlike organisms form a very tight clade in srDNA phylogenies, and there are very few sequence differences between them (Stokes et al. 2002), despite their collection from different areas along the east coast of the United States. The QPX primers used for the second amplification appear to be specific for this group based upon sequence alignment comparisons and probe homology searches at GenBank and the Ribosomal Database Project, but there is the possibility that they will amplify unidentified organisms from environmental samples. DGGE analysis allows visual determination of the presence of bands different from those of the QPX culture, and they can be targeted for sequence analysis.

As mentioned earlier, the DGGE method is able to separate fragments that have single base differences, but it can be difficult to uncover a single-base difference when directly sequencing reamplified DGGE products. There are sometimes ambiguities that cannot be resolved, it is difficult to obtain the full sequence, and the error rate of sequencing can be as great as $1 \%$ (2.5 bases in a 250 bp DGGE fragment). Several of the bands recovered from different positions had sequences considered identical to QPX (>99\% similarity). Most of these bands were also present in the QPX culture amplification products and could represent artifacts caused by the overabundance of template DNA (particularly in the case of the QPX culture) or the formation and accumulation of spurious products due to the repeated amplifications, the presence of multiple, slightly different copies of the gene in a single cell, or to the presence of different strains of QPX. Most of the products are reproducible and appear spe- cific to the presence of QPX (see culture positive control, Fig. 2). In the case of Seed Clam B22 (Lane 9; Fig. 5), the band recovered was not present in the QPX control, and its sequence had only a single-base difference from that of QPX. This small difference is not sufficient to establish it as a different QPX strain. Further study of this particular sample will be informative.

What is noteworthy about this work is that we have been able to detect the presence of the QPX organism in natural samples (seed clams), as well as confirm its identity using this method. DGGE is an essential component in the nested PCR process. Environmental samples can be extremely complex with regard to their microbial composition, and we have hardly begun characterizing the ribosomal genes of all of the organisms present. Therefore, organism-specific PCR of environmental samples will always be suspect (to some extent) without sequence information to provide confirmation of that specificity. DGGE allows sequencebased separation of similarly sized PCR products, something an agarose gel cannot provide. We have shown that bands matching the position of the positive control can be considered positive for the QPX organism, while bands that occur at other positions have to be recovered and sequenced to establish their taxonomic relationships.

A further significant observation of this work is that small $(15 \mathrm{~mm})$ seed clams can accumulate QPX particles. A previous study was unable to find QPX infections by histology in hatchery seed (Ford et al. 1997), which led to the suggestion that hard clams became parasitized during field grow-out. The seed clams that we analyzed had been planted for grow-out in an area that was experiencing QPX-associated mortality. Histological analysis of duplicate sets of seed clams found that only 1 of the Group A seed clams actually had an infection (R. Smolowitz unpubl. data). Because we did not wash the mantles and siphons prior to extraction of our clam tissues, our work does not indicate that the small clams were infected, but that they were exposed to and able to accumulate the parasite in their mantle fluid or pseudofeces. This is significant, because seed clams are routinely planted at extremely high density in aquaculture plots. With $10 \%$ of the population carrying at least 10 QPX organisms, there is the potential for tens to hundreds of thousands of viable QPX cells to be released into the environment simply through the release of pseudofeces or mantle fluid in a newly planted plot. We base this calculation on a minimum detection limit of 10 QPX organisms clam ${ }^{-1}$ and the fact that seed is often planted at a density of $100{\text { clams } \mathrm{ft}^{-2}}^{-2}$ (1075 clams $\mathrm{m}^{-2}$ ).

QPX is a thraustochytrid, and organisms in this group are routinely found on decaying macrophytes in the marine environment. It is highly likely that the 
QPX organism would be able to survive outside of its host and would persist in an environment once it had been introduced. Work by Lyons et al. (2005) has shown that QPX can be found in marine aggregates in areas currently showing QPX-induced mortality, as well as areas that have not shown QPX mortality in several years. We are currently expanding upon Lyons work by using the detection method described in this manuscript to screen and monitor infected and uninfected clam plots. This will provide information on the distribution and persistence of QPX in the water and sediment, as well as determine whether other invertebrates or macrophytes in the area are potential alternative hosts for the parasite. We advocate the screening of hard clam seed prior to replanting, and strongly discourage the grow-out of seed in areas where QPX is present or has recently occurred, to help prevent the spread of this disease to new areas and to reduce the mortality of newly planted plots.

Acknowledgements. This manuscript is a result of research sponsored by NOAA National Sea Grant College Program Office, Department of Commerce, under Grant No. NA16RG2273, Woods Hole Oceanographic Institution Sea Grant Project No. R/B-168. The views expressed herein are those of the authors and do not necessarily reflect the views of NOAA or any of its subagencies. We thank Tom Marcotti (shellfish warden for the town of Barnstable) for providing seed clams for analysis, and the WHOI Summer Student Fellow Program for their support of the undergraduate student E.C. in the summer of 2004. WHOI Contribution No. 11346.

\section{LITERATURE CITED}

Altschul SF, Madden TL, Schaffer AA, Zhang J, Zhang Z, Miller W, Lipman DJ (1997) Gapped BLAST and PSIBLAST: a new generation of protein database search programs. Nucleic Acids Res 25:3389-3402

Austin B (1988) Quantification of marine microbial populations. Marine microbiology. Cambridge University Press, Cambridge, p 31-44

Brothers C, Marks E III, Smolowitz R (2000) Conditions affecting the growth and zoosporulation of the protistan parasite QPX in culture. Biol Bull (Woods Hole) 199:200-201

Cole JR, Chai B, Farris RJ, Wang Q, Kulam SA, McGarrell

Editorial responsibility: Albert K. Sparks,

Seattle, Washington, DC, USA
DM, Garrity GM, Tiedje JM (2005) The Ribosomal Database Project (RDP-II): sequences and tools for highthroughput rRNA analysis. Nucleic Acids Res 33: D294-D296

Drinnan RE, Henderson EB (1963) 1962 mortalities and possible disease organism in Neguac quahogs. Annual Report No. B11, Biological Station, St. Andrews, NB

Ford SE, Smolowitz R, Ragone Calvo LM, Barber RD, Kraeutner JN (1997) Evidence that QPX (quahog parasite unknown) is not present in hatchery-produced hard clam seed. J Shellfish Res 16:519-521

Gast RJ, Dennett MR, Caron DA (2004) Characterization of protistan assemblages in the Ross Sea, Antarctica by denaturing gradient gel electrophoresis. Appl Environ Microbiol 70:2028-2037

Kanagawa T (2003) Bias and artifacts in multitemplate polymerase chain reactions (PCR). J Biosci Bioeng 96:317-323

Kleinschuster SJ, Smolowitz R, Parent J (1998) In vitro life cycle and propagation of Quahog Parasite Unknown. J Shellfish Res 17:75-78

Lyons MM, Ward JE, Smolowitz R, Uhlinger KR, Gast RJ (2005) Lethal marine snow: pathogen of bivalve mollusc concealed in marine aggregates. Limnol Oceanogr 50:1983-1988

Maas PAY, Kleinshuster SJ, Dykstra MJ, Smolowitz R, Parent J (1999) Molecular characterization of QPX (Quahog Parasite Unknown), a pathogen of Mercenaria mercenaria. J Shellfish Res 18:561-567

Mo C, Douek J, Rinkevich B (2002) Development of a PCR strategy for thraustochytrid identification based on $18 \mathrm{~S}$ rDNA sequence. Mar Biol 140:883-889

Smolowitz R, Leavitt D, Perkins F (1998) Observations of a protistan disease similar to QPX in Mercenaria mercenaria (hard clams) from the coast of Massachusetts. J Invertebr Pathol 71:9-25

Smolowitz R, Leavitt D, Lancaster B, Marks E, Hanselmann R, Brothers C (2001) Laboratory based transmission studies of quahog parasite unknown (QPX) in Mercenaria mercenaria. Aquaculture (book of abstracts) 2001:599

Spatz MJ, Anderson JL, Jancart S (1996) Northeast region aquaculture situation and outlook report. Report No. 3352, Northeastern Regional Aquaculture Center, Rhode Island Agricultural Experiment Station, Kingston, RI

Stokes NA, Ragone Calvo LM, Reece KS, Burreson EM (2002) Molecular diagnostics, field validation, and phylogenetic analysis of Quahog Parasite Unknown (QPX), a pathogen of the hard clam Mercenaria mercenaria. Dis Aquat Org 52:233-247

Whyte SK, Cawthorn RJ, McGladdery SE (1994) QPX (Quahaug Parasite X) a pathogen of northern quahaug Mercenaria mercenaria from the Gulf of St. Lawrence, Canada. Dis Aquat Org 19:129-136

Submitted: April 17, 2005; Accepted: December 26, 2005

Proofs received from author(s): April 24, 2006 